\section{Manifiesto de Niños, o la escenificación de la violencia}

María Laura Ríos*

\begin{abstract}
Resumen: Sin lugar a dudas con Manifiesto de Niños, el colectivo teatral El periférico de Objetos redobla su apuesta en lo que viene siendo una propuesta estética altamente arriesgada al ofrecernos algo así como una "instalación teatral de la violencia" mediante la utilización recrudecida del impacto emocional sobre el espectador. La obra fuerza hasta límites insospechados la tolerancia visual del receptor y plantea la anatomía de una claustrofóbica experimental que intenta denunciar la violencia ejercida sobre los niños. Los resultados de esta experiencia invocan hacia una reflexión sobre una poética que explora la profunda abyección de la pulsión escópica del espectador mediante una organización discursiva extremadamente opresiva.
\end{abstract}

Palabras claves: directores teatrales argentinos - El periférico de Objetos - experimentación - puesta en escena - teatro postmoderno - violencia infantil.

[Resúmenes en inglés y portugués y currículum en la página 39]

Generalmente un manifiesto es una declaración escrita de principios que se caracteriza por trazar una serie de estrategias a ser llevadas a cabo por un grupo de personas para la obtención de determinados fines. Siguiendo esta particular directriz uno puede encontrarse con la última obra de El Periférico de Objetos, Manifiesto de Niños, y tratar de desentrañar una compleja propuesta que intenta denunciar la violencia ejercida en torno a los niños. Mediante esta particular forma de "declaración escénica" se asiste a una progresiva señalización de los silenciamientos al que es sometido el universo infantil pero también plantea un serio interrogante sobre los modos de concretizar una textualidad de la permanente provocación emocional.

Una primera aproximación a la puesta en escena de Manifiesto de Niños permite dilucidar una estructura en la que se tensan simultáneamente diversos elementos audiovisuales y preformativos encargados de garantizar una agobiante simbólica de la violencia montada en torno de una instalación. En este caso se trata de una idea de instalación como itinerario que se "transforma en un objeto recorrido por la mirada deconstructora y [...] por el desplazamiento físico del público frente a espacios de actuación" (Pavis, 2005: 263). El primer impacto visual inaugura el contacto con un enorme cubo hermético en el que se hallan "recluidos" tres intérpretes. Esto permite, por un lado, observar por fuera sus acciones mediante una estrecha ventana. Pero, por otro, ofrece la posibilidad del desplazamiento o de seguir fragmentadamente algunos eventos que se suceden dentro del habitáculo a través unas pantallas externas encargadas de proyectar y amplificar visualmente una interacción que involucra la manipulación encarnizada de juguetes articulados y pequeños muñequitos Playmobil. Mientras que una actriz caracterizada como un ser aniñado comienza con la 
enumeración interminable de un listado con los nombres, apellidos, edades y nacionalidades de niños asesinados por todo el planeta; otros dos personajes individualizados en enigmáticos "payasos de lo ominoso" se encargan de enjuiciar y sentenciar la culpabilidad de niños cosificados como verdaderos juguetes de los adultos. Esta suerte de monólogo alienado culmina con el afligido llanto de la actriz y desarticula de modo extremadamente agresivo la turbada emocionalidad del público. Ya hacia el final de la obra, los verdugos de lo infantil abandonan esa extraño role-playing, mezcla de terrorismo lúdico y "pedagogía de la crueldad", para interactuar con el público mediante el ofrecimiento del cuidado de pequeños retratos infantiles.

\section{Hacia un terrorismo emocional}

A partir de esta breve descripción de la puesta en escena de Manifiesto de Niños es posible pensar una poética de la teatral como el efecto de un asedio. El asedio de un orden donde la sensibilidad visual del espectador recibe el imperativo de un régimen de visibilidad absoluta mediante esta especie de emergencia alucinada de las imágenes. Es entonces donde quizás la violencia se erige desde ese forzamiento de la mirada que muchas veces no puede distinguir con nitidez entre el abuso y el culto ilimitado de la pulsión escópica. Un suplemento que ya no trasunta la mera transgresión de las formas teatrales y sus modos de apreciación estética sino que pervierte una vectorización de las fuerzas dramáticas hacia una trampa espectacular que imposibilita el trayecto de la simbolización para conformar un encierro enunciativo. Es hacia este lugar que la obra tiende un trayecto donde la mirada, lejos de ser tranquilizadora, pro-yecta (o eyecta) hacia un espacio impúdico en el que el espectador "habita" la indefensión. Esta textualidad que intenta desacomodar la pasividad bordea unos límites de la sensibilidad estética, y sobre todo ética que, agobia el orden de la comprensión. Un teatro de la opresión significante que a veces significa pocas cosas.

Con Manifiesto de niños el sistema de la interpretación escénica parte desde una exaltación del ¿sinsentido-de-la-violencia? como un formidable rito lúdico. La evolución dela retórica del pathos dramático y su vinculación con el espacio actoral, que es al mismo tiempo un espacio de detención, impone la implosión de una ceremonia de "terrorismo emocional". Este procedimiento que silencia, pero que al mismo tiempo exclama, enuncia un gesto subrepticio en la que la verdadera voz de lo infantil se torna en un objeto subalterno y cosificado. Por esta razón los juguetes, transformados en objetos escénicos, constituyen una perversa metáfora del niño como un sujeto imposibilitado de otorgar cuerpo, por la muerte, por la ausencia, por ser niño. Y sí los diálogos partidos en mil pedazos, y sí la irreversibilidad de un manifiesto dicho por ningún chico es la complicidad de un silencio que niega por pasividad, y también por estetización, entonces quizás los adultos seamos los auténticos verdugos.

El peligro que muestra uno de los más álgidos momentos meta-dramáticos de la obra evidencia a uno de los intérpretes-verdugos exhibiendo un falso y enorme sexo masculino de plástico como un artefacto obsceno que juguetea con una muñeca dentro de un pequeño escenario de títeres, una renovada provocación de nuestra condición escópica. En dicha presencia de la representación dentro de la presentación se evidencia el totalitarismo de la observación desvergonzada del que mira y es mirado. Esta manipulación como estrategia de construcción discursiva en la que la violencia se plantea como una espectacularización del exceso involucra la ostención del desarreglo moral generalizado y la incertidumbre del estatuto epistémico de la recepción en la actualidad.

Una vez más El periférico de Objetos coloca en el centro de su exploración teatral el inquietante enigma de la construcción de la obra a partir de la interpelación hacia el espectador, ese extraño 
sujeto colectivo, mediante procedimientos multi-mediáticos creando un éxtasis ficcional que recrea la condición del "verdadero reality show".

\section{Bibliografía}

Pavis, Patrice. (2005). Diccionario del Teatro. Buenos Aires: Paidós Comunicación, p. 263.

\section{Ficha técnica}

Dirección: Ana Alvarado, Emilio García Wehbi, Daniel Veronese Intérpretes: Maricel Alvarez, Blas Arrese Igor, Emilio García Wehbi

Voz en off: Horacio González-Máscaras: Alejandra Farley-Diseño de maquillaje: Marcelo Martínez-Realización escenográfica: Ariel Vaccaro-Realización de muñecos: Alejandra Ferley-Video: Phillip Basté-Música: Marcelo MartínezAsistencia de Dirección: Felicitas Luna-Producción: Maricel Alvarez, Felicitas Luna

Summary: Undoubtedly, the Manifest of Children, included in the theater play group The peripheral of objects, redoubles its bet in what can be called a "theater installation of violence" by means of the use of the emotional impact in the frame of an aesthetic proposal to the audience. The play pushes to unsuspected limits the visual tolerance of the audience in the attempt to denounce the violence exerted on children. The results of this experience invoke towards a reflection on a poetic that explores the deep abjection of the pressure on the spectator by means of an extremely oppressive discursive organization.

Key words: argentine theater directors - The peripheral of Objects - experimentation - staging - postmodern theater violence against children.

Resumo: Sem lugar a dúvidas com Manifesto de Meninos, o coletivo teatral O periférico de Objetos redobra seu aposta no que vem sendo uma proposta estética altamente arriscada ao oferecer-nos algo bem como uma "instalação teatral da violência" mediante a utilização do impacto emocional sobre o espectador. A obra força até limites insuspeitos a tolerância visual do receptor, e propõe a anatomia de uma claustrofóbica experimental que tenta denunciar a violência exercida sobre os meninos. Os resultados desta experiência levam a uma reflexão sobre uma poética que explora o despreço ao impulso escópico do espectador mediante uma organização discursiva opresiva.

Palavras chave: diretores teatrais argentinos - O periférico de Objetos - experimentação - posta em cena - teatro postmoderno - violência infantil.

${ }^{(*)}$ Licenciada en Artes (UBA). Investigadora en el Instituto de Artes del Espectáculo, Facultad de Filosofía y Letras (UBA). Docente de la Facultad de Diseño y Comunicación de la UP. 